\title{
Zapis aleatoryzmu kontrolowanego jako instrukcja działania dla wykonawców na wybranych przykładach kompozycji Witolda Lutosławskiego.
}

\section{Transcription of controlled aleatorism as an instruction for performers based on selected pieces by Witold Lutosławski.}

\author{
Jakub Chrenowicz \\ AKademia MuZYCZNA IM. I. J. PADEREWSKIEgO \\ UL. ŚW. MARCIN 87, 60-101 POZNAŃ \\ jakub.chrenowicz@gmail.com
}

\begin{abstract}
The goal of the article is to present the transcription system in Witold Lutosławski's pieces composed using the technique of controlled aleatorism as a formal language for the transmission of instructions to the conductor and orchestra musicians performing those works. The starting point for my ruminations is to explore controlled aleatorism from the performer's perspective.The text invokes excerpts from three pieces by Witold Lutosławski: Cello concerto, Chain I, and Piano Concerto. The author presents an account of the controlled aleatorism technique and analyzes the graphic signs used in the aforementioned compositions, along with the ways in which they are interpreted by performers. The author contends that the examined transcriptions are a collection of instructions of varying degrees of complexity, addressed to musicians performing the analyzed pieces. Such a system of notation can be interpreted as a formal language which the composer programmed the work of the conductor and orchestra musicians. Beginning with the simplest instructions, he proceeded to create complex, algorithmic commands. The conclusions drawn from the above analyses point to the essence of controlled aleatorism in music notation and its interpretations. The element of control overrides the element of randomness, and such a state of affairs is attained by using a particular type of transcription.
\end{abstract}




\section{Wprowadzenie}

Muzyczny aleatoryzm (alea łac. kości do gry, hazard) zakłada zastosowanie w procesie realizacji dzieła przypadku i losowości. Mogą elementy aleatoryczne wpływać na formę dzieła przez pozostawienie wykonawcy decyzji o kolejności wykonania fragmentów kompozycji (jak w utworze $A$ piacere Kazimierza Serockiego). Może losowości podlegać sam materiał muzyczny - wysokości i czas trwania poszczególnych dźwięków. Czasem, w kompozycjach aleatorycznych totalnie, (jak Koncert fortepianowy Johna Cage'a) losowi, bądź decyzji wykonawcy pozostawiony może być wybór obsady wykonawczej oraz rozstrzygnięcie czy $\mathrm{w}$ ogóle wydać dźwięk $\mathrm{z}$ instrumentów. Technikę aleatoryzmu kontrolowanego Witold Lutosławski po raz pierwszy zastosował w powstałej w 1961 roku kompozycji Gry weneckie. Kompozytor użył niedookreślenia, niedokomponowania pewnych elementów dzieła muzycznego. Jak pisze Bohdan Pociej:

„Chodzi tu o pewną otwartość, o pewne miejsca
otwarte w ramach ściśle skomponowanej i
zamkniętej struktury całości dzieła; miejsca
świadomie niedokomponowane i powierzone
inwencji wykonawców" (Pociej 1976: 55 ).

Użyte zostało jednak niedokomponowanie w sposób niezwykle zdyscyplinowany, a przypadkowość ują kompozytor w ramy, które nie pozwalają wykonawcy na zrealizowanie idei brzmieniowej utworu w sposób, którego nie życzyłby sobie twórca.

$\mathrm{W}$ niniejszym artykule autor analizuje stworzone $\mathrm{z}$ użyciem techniki aleatoryzmu kontrolowanego fragmenty Koncertu wiolonczelowego, Eańcucha I oraz Koncertu fortepianowego Witolda Lutosławskiego.

Jest ta analiza owocem zainteresowania autora rolą dyrygenta w kompozycjach aleatorycznych Witolda Lutosławskiego. Dysertacja doktorska autora traktowała o Grach weneckich oraz Koncercie fortepianowym, kompozycjach powstałych w odstępie ponad dwudziestu lat, reprezentujących różne okresy twórczości kompozytora oraz nieco odmienne sposoby użycia analizowanej techniki. Trzy utwory przytoczone w niniejszym artykule stosują wspomnianą technikę kompozytorską w całkowicie wykrystalizowanej na przestrzeni lat formie, można na ich przykładzie wskazać cechy reprezentatywne dla dojrzałej techniki aleatoryzmu kontrolowanego.

Motywacja do napisania niniejszego artykułu pochodzi także z działalności artystycznej autora, który wszystkie analizowane zarówno w pracy doktorskiej, jak i w tekście niniejszym kompozycje wykonał jako dyrygent. Doświadczenie praktyka może okazać się cenne w opisywaniu bardzo nietradycyjnego zapisu muzycznego, będącego swoistą instrukcją działania 
przeznaczoną dla wykonawców, stawiającego dyrygenta w roli osoby strzegącej odpowiedniego odczytywania tej instrukcji.

Autor stawia tezę, że zapis aleatoryzmu kontrolowanego nie jest próbą odwzorowania brzmienia, lecz zestawem instrukcji dla wykonawców, rodzajem zapisu algorytmów.

Podstawową metodą badawczą jest analiza partytury ze szczególnym zwróceniem uwagi na znaki graficzne stworzone przez Witolda Lutosławskiego. Autor dokonał klasyfikacji znaków uwzględniając sposób odczytywania ich przez wykonawców oraz ilość i rodzaj informacji, które przekazują.

Posługując się aparatem pojęciowym z dziedzin nauki zajmujących się przetwarzaniem informacji wskazał na obecność w partyturze ciągów komunikatów tworzących złożone struktury, będące instrukcjami dla wykonawców.

\section{Znaki graficzne zastosowane przez Witolda Lutosławskiego}

Elementem, na którym Witold Lutosławski zbudował metodę zapisu aleatoryzmu kontrolowanego są stworzone przez niego znaki graficzne. Kompozytor za ich pomocą wskazal moment wykonania ruchu przez dyrygenta, adresata tego ruchu oraz sposób interpretacji ruchu. Można te znaki przeanalizować na przykładzie fragmentów partytury Łańcucha I. Pierwszy z opisywanych znaków przedstawia poniższa rycina.

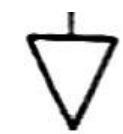

Ryc. 1

Strzałka ta oznacza wykonanie ruchu przeznaczonego dla całego zespołu. Ruch wskazuje wejścia oraz jest komunikatem do zakończenia gry.

Na przedstawionym na ryc. 4 przykładzie można zaobserwować użycie znaku w zapisie partyturowym i tak ruch $\mathrm{nr} 15$ jet sygnałem dla muzyków grających na instrumentach smyczkowych do zakończenia gry, a dla klarnecisty będzie wskazaniem wejścia. 


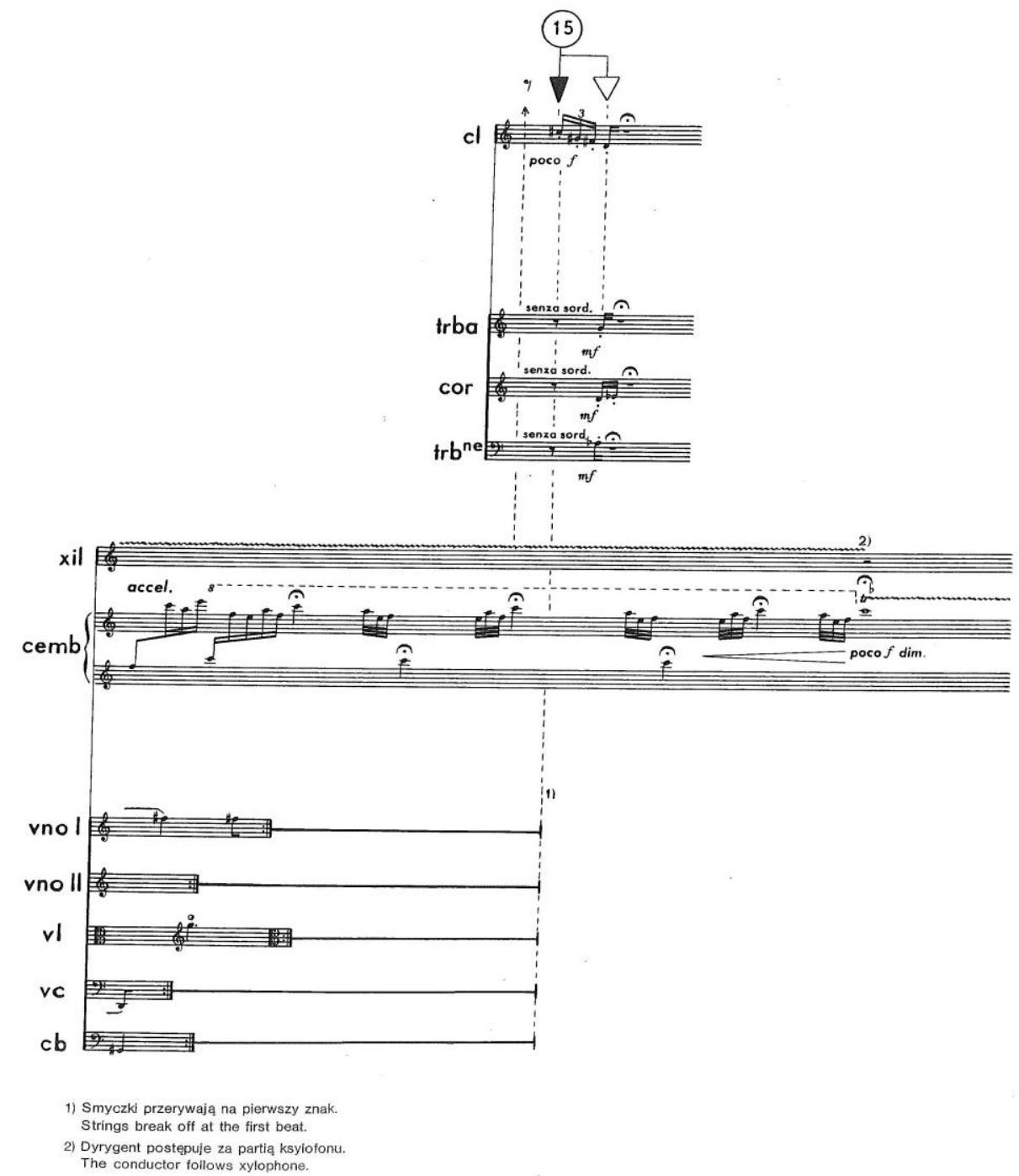

Ryc. 2

Kolejny znak nakazuje dyrygentowi zaadresowanie ruchu do konkretnych muzyków, tylko oni będą według jego ruchu rozpoczynać, lub kończyć realizację swojej partii.

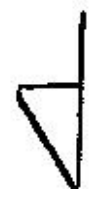

Ryc. 3 
Widoczny w tym fragmencie partytury znak przeznaczony jest jedynie dla waltornisty, za jego pomocą dyrygent wskazuje moment rozpoczęcia

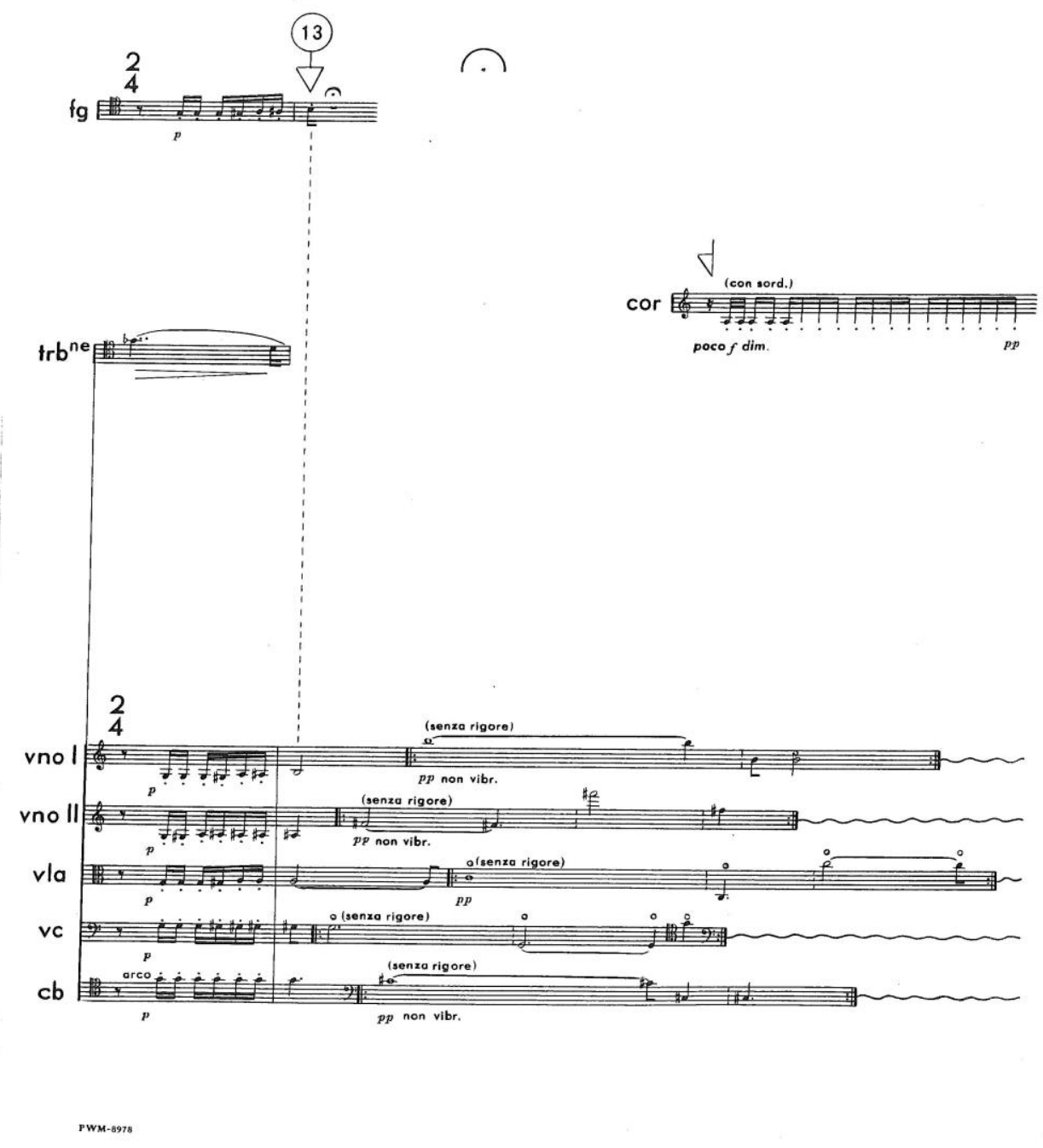

realizacji partii waltorni.

Ryc. 4

Obydwa powyżej przedstawione znaki mogą w różnych utworach Witolda Lutosławskiego minimalnie różnić się pod względem dokładnego kształtu, bądź koloru (czerni lub bieli), natomiast zawsze strzałka „pełna" oznacza ruch oburącz dla całej orkiestry, a „pół" strzałki będzie gestem adresowanym do mniejszej grupy lub jednej osoby, który można wykonać lewą ręką.

Dalej analizowane znaki odnoszą się do bardzo częstej sytuacji w muzyce Witolda Lutosławskiego, kiedy to instrumentaliści powtarzają 
wskazane fragmenty w sposób ciągły. Zabieg taki jest typowy dla aleatoryzmu kontrolowanego i gwarantuje wystąpienie pewnej losowości $\mathrm{w}$ przebiegu realizacji dzieła. Partie powtarzane w ciąglej repetycji, przez każdego muzyka niezależnie, bez rygoru rytmicznego, wprowadzają element przypadkowości, na którym analizowana technika się opiera. Dwa znaki przedstawione poniżej informują muzyków grających w ciągłej repetycji w jaki sposób interpretować ruch dyrygenta.

Pierwszy z nich przedstawiony jest na ryc.5.

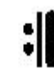

Ryc. 5

Oznacza ten znak graficzny konieczność powtarzania zaznaczonego fragmentu oraz naty chmiastowe przerwanie gry wraz z ruchem dyrygenta.

Poniższa rycina prezentuje użycie znaku $\mathrm{w}$ zapisie partyturowym w sytuacji, w której muzycy grający na instrumentach smyczkowych powinni przerwać grę dokładnie $\mathrm{z}$ ruchem dyrygenta oznaczonym numerem 15 . 
14

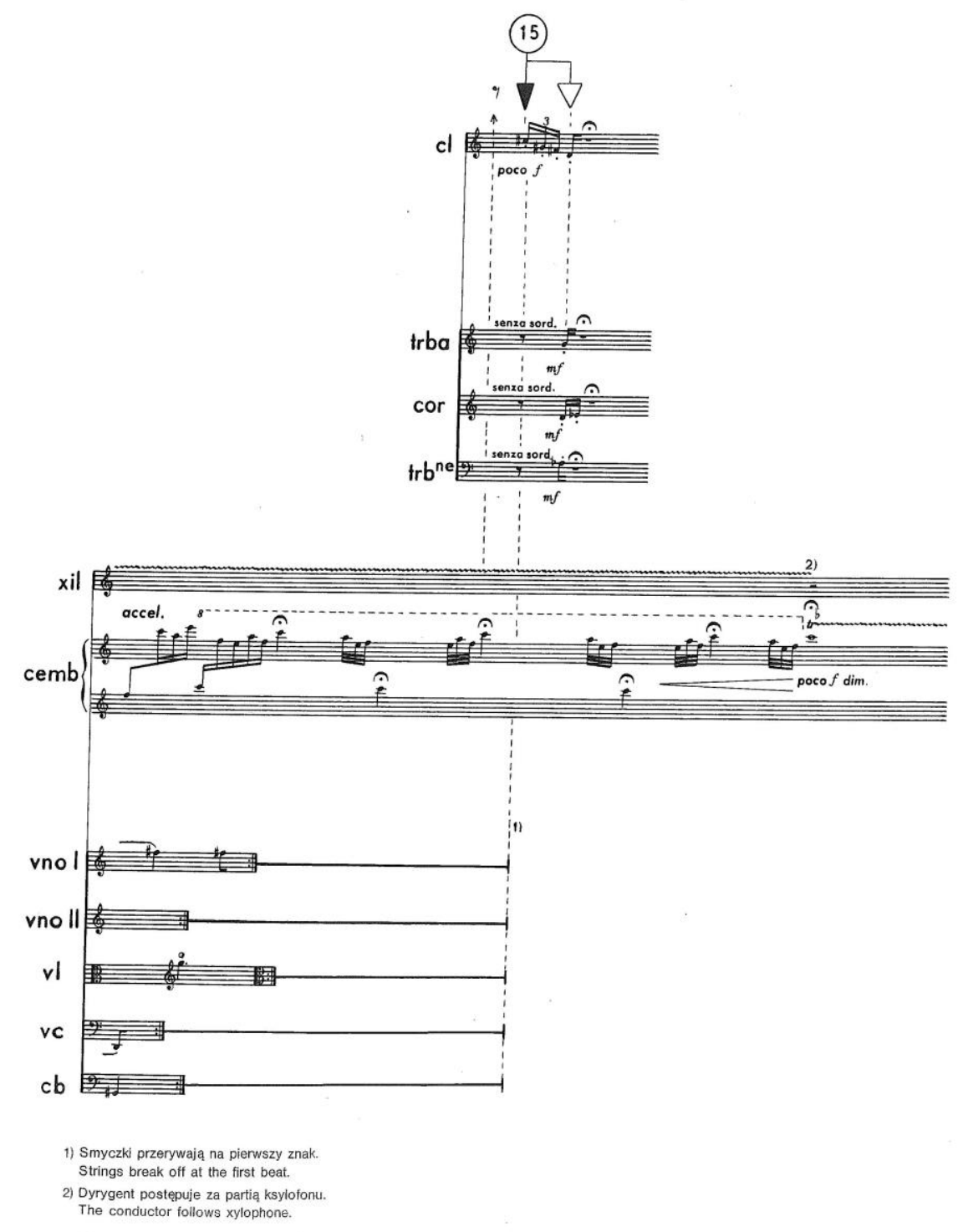

Ryc. 6

Kolejny $\mathrm{z}$ podstawowych znaków zastosowanych przez Witolda Lutosławskiego przedstawia się następująco:

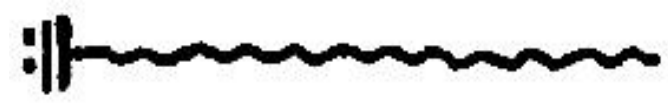

Ryc. 7

Muzycy powinni wykonywać swoje partie w ciągłej repetycji, natomiast po ruchu dyrygenta nie przerywać natychmiast, ale dokończyć realizowaną właśnie powtórkę i dopiero skończyć, bądź przejść do grania kolejnego fragmentu. Przestawia tę sytuację kolejna rycina. Muzycy grający na 
JAKUB CHRENOWICZ: ZAPIS ALEATORYZMU KONTROLOWANEGO JAKO INSTRUKCJA DZIAEANIA DLA WYKONAWCÓW NA WYBRANYCH PRZYKŁADACH KOMPOZYCJI WITOLDA LUTOSEAWSKIEGO

instrumentach smyczkowych realizują swoje partie w ciągłej repetycji, aż do momentu, w którym dyrygent wykona ruch nr 14. Wtedy każdy z muzyków (w sposób niezależny) dogrywa do znaku repetycji bądź pionowej przerywanej linii i przechodzi do realizowania partii zapisanej za analizowanym znakiem.



Ryc. 8

Przeanalizowane znaki wraz z dokładnym sposobem ich odczytania zostały zestawione w tabeli 1 .

Tabela nr 1: Zestawienie znaków.

Znak

Sposób odczytania znaku 


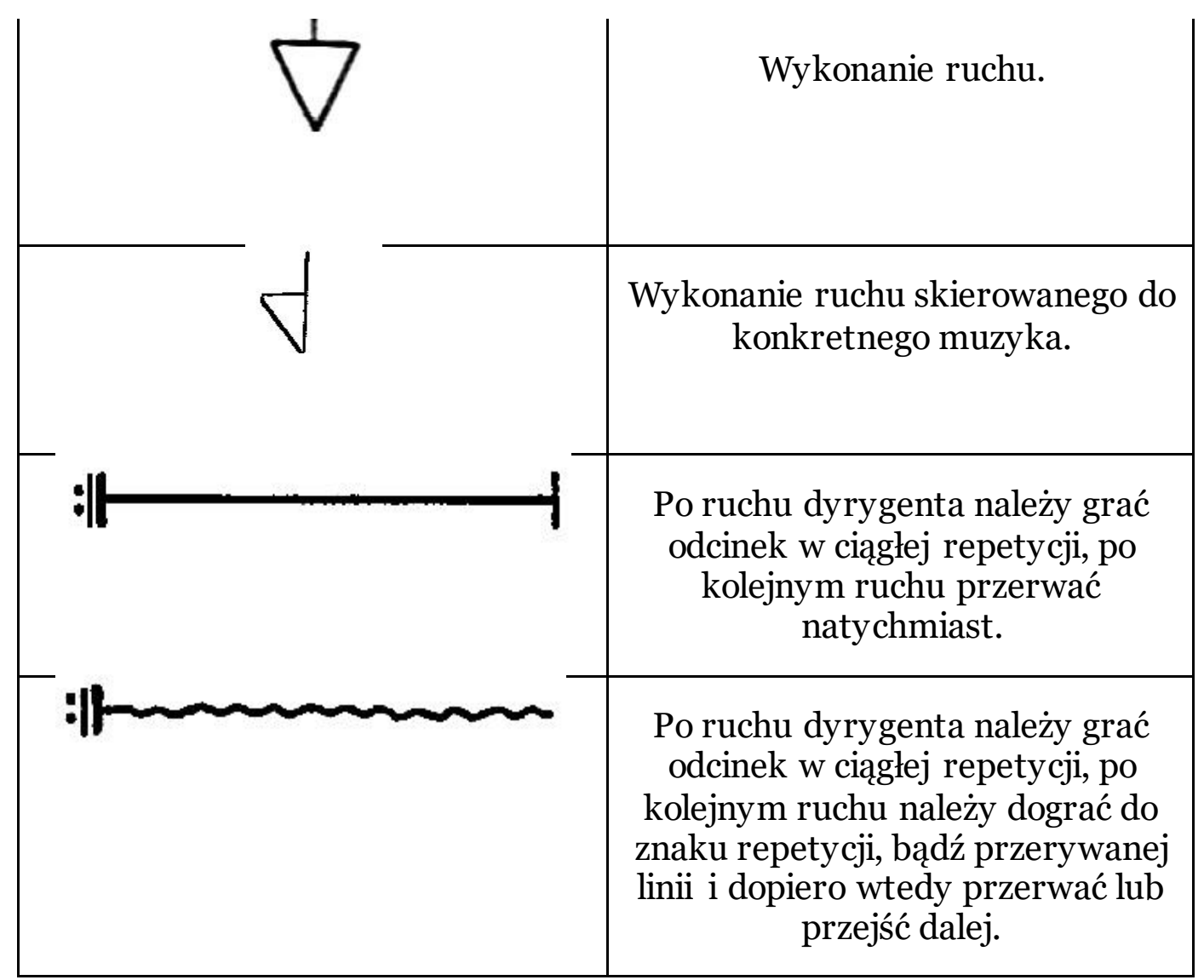

Można zauważyć, że znaki zastosowane przez Witolda Lutosławskiego przekazują nie tylko różne rodzaje informacji, ale także inną jej ilość. Kolejna rycina przedstawia podział znaków ze względu na ilość informacji, którą zawierają komunikaty przez nie przekazywane. 


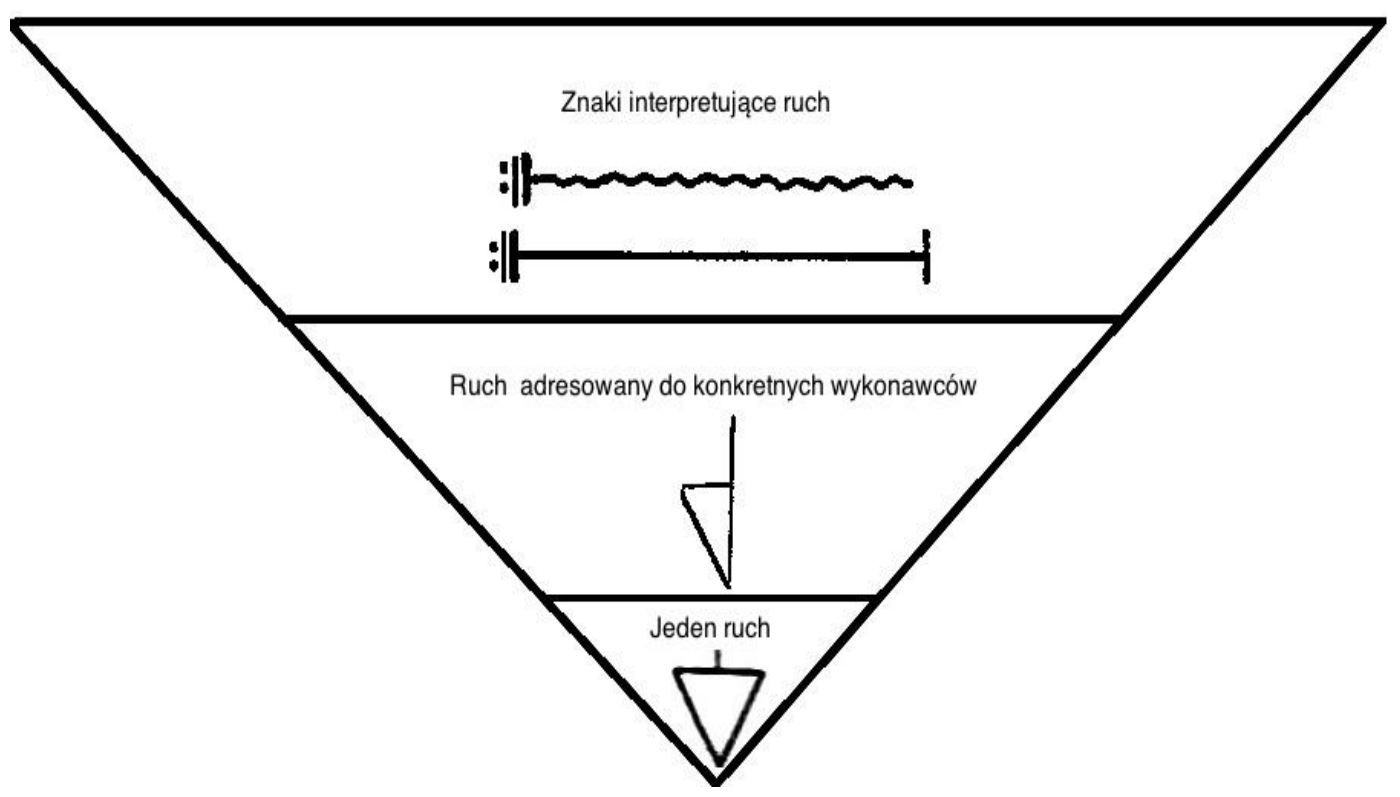

Ryc. 9

Najmniejszą ilością informacji, którą przekazują znaki zastosowane przez Witolda Lutosławskiego jest komunikat: „wykonaj ruch". Taką ilość informacji przekazuje strzałka zamieszczona na dole grafiki. Nośnikiem większej ilości informacji są znaki, które ruch każą dyrygentowi zaadresować do konkretnego muzyka, bądź grupy. Poza komunikatem: „wykonaj ruch", przekazują też informację do kogo. Jest to drugi poziom w hierarchii. Największą ilość informacji przekazują znaki znajdujące się na górze ryciny. Informują one muzyków orkiestry jakie czynności powinni realizować, po wykonaniu ruchu przez dyrygenta. Znaki te zawierają także komunikat dla dyrygenta: „po ruchu czekaj, aż wskazani muzycy będą realizować swoje partie $\mathrm{w}$ ciągłej repetycji, dopiero $\mathrm{w}$ takiej sytuacji wykonaj kolejny ruch".

\section{Zapis aleatoryzmu kontrolowanego jako język formalny}

Z przeanalizowanych znaków kompozytor stworzył złożone struktury przedstawiające zestawy czynności przeznaczone do realizacji przez wykonawców. Każdy z zamkniętych odcinków utworów wymaga wykonania ściśle określonych kroków, co więcej - przejście między kolejnymi krokami odbywa się według szczegółowych wytycznych.

Przykładem odcinka muzycznego złożonego z takich kroków jest fragment początkowy pierwszej części Koncertu fortepianowego przedstawiony na poniższej rycinie. 
Investigationes Linguisticae, vol. XXXVI

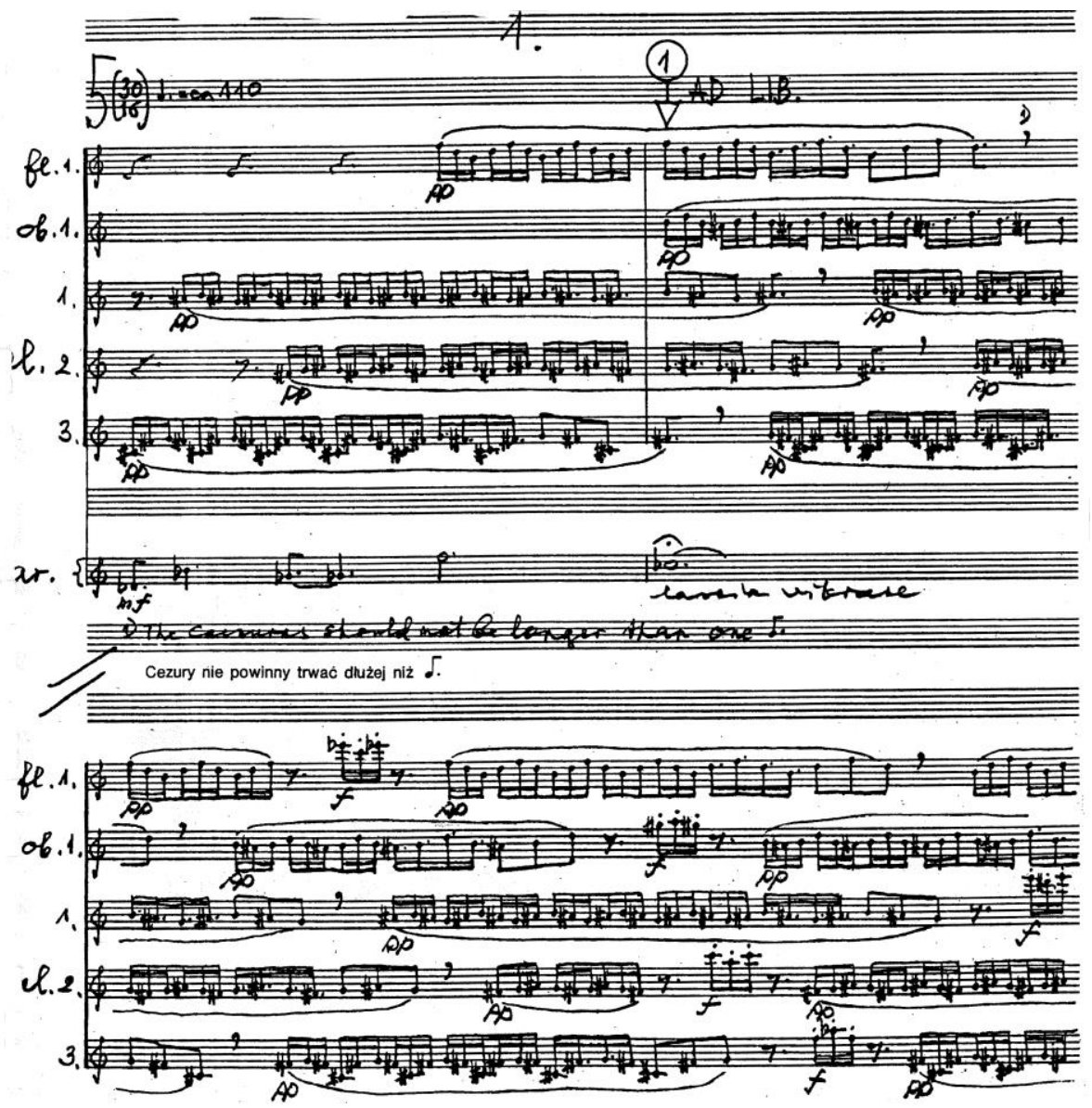

Ryc. 10

Po wykonaniu ruchu $\mathrm{nr}$ 1, który rozpoczyna odcinek aleatoryczny, muzy cy wykonują swoje partie w ciągłej repetycji, 
JAKUB CHRENOWICZ: ZAPIS ALEATORYZMU KONTROLOWANEGO JAKO INSTRUKCJA DZIAEANIA DLA WYKONAWCÓW NA WYBRANYCH PRZYKŁADACH KOMPOZYCJI WITOLDA LUTOSEAWSKIEGO
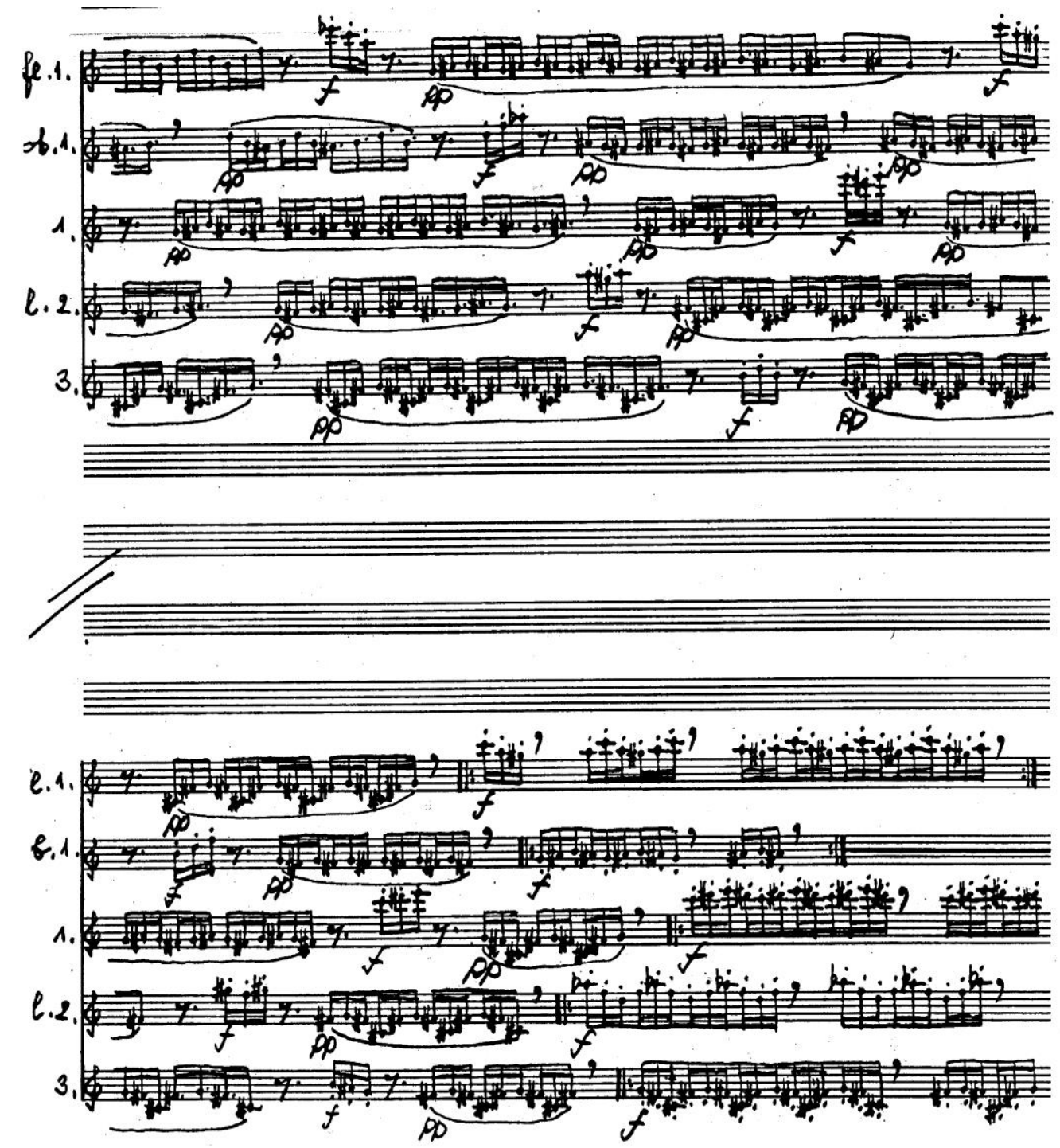

Ryc. 11

Linie ciąłe oznaczaja konieczność powtarzania partii i przerwania gry natychmiast $\mathrm{z}$ ruchem dyrygenta. Dyrygent wykonuje pięć ruchów przeznaczonych do kolejnych muzyków. 


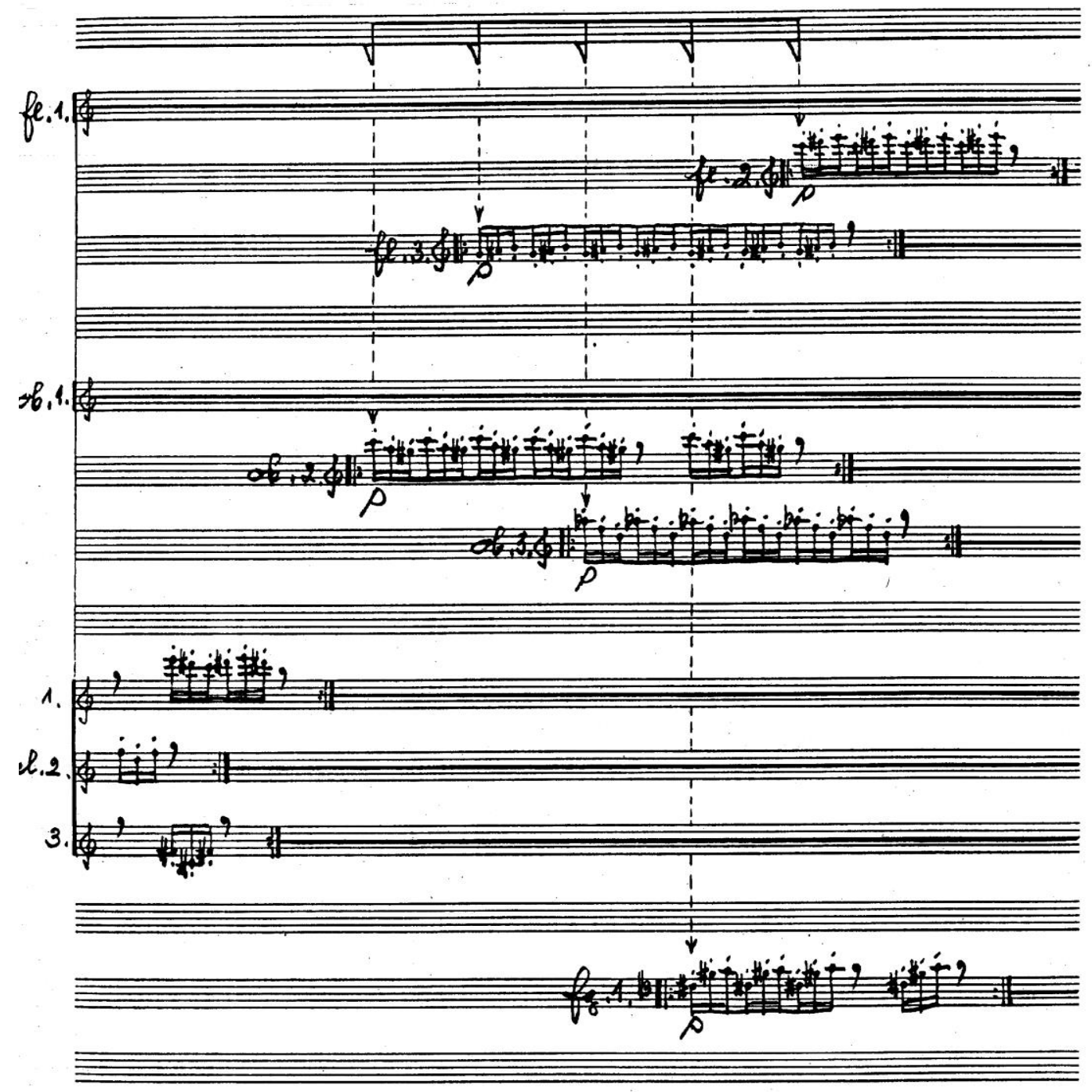

Ryc. 12

Gdy już wszyscy powtarzają swoje partie w nieustannej repetycji, w sposób od siebie niezależny, dyrygent kończy bieżący odcinek, zaczyna dyrygować kolejny fragment. Ten moment zaobserwować można na rycinie 13 . 
JAKUB CHRENOWICZ: ZAPIS ALEATORYZMU KONTROLOWANEGO JAKO INSTRUKCJA DZIAEANIA DLA WYKONAWCÓW NA WYBRANYCH PRZYKAADACH KOMPOZYCJI WITOLDA LUTOSEAWSKIEGO
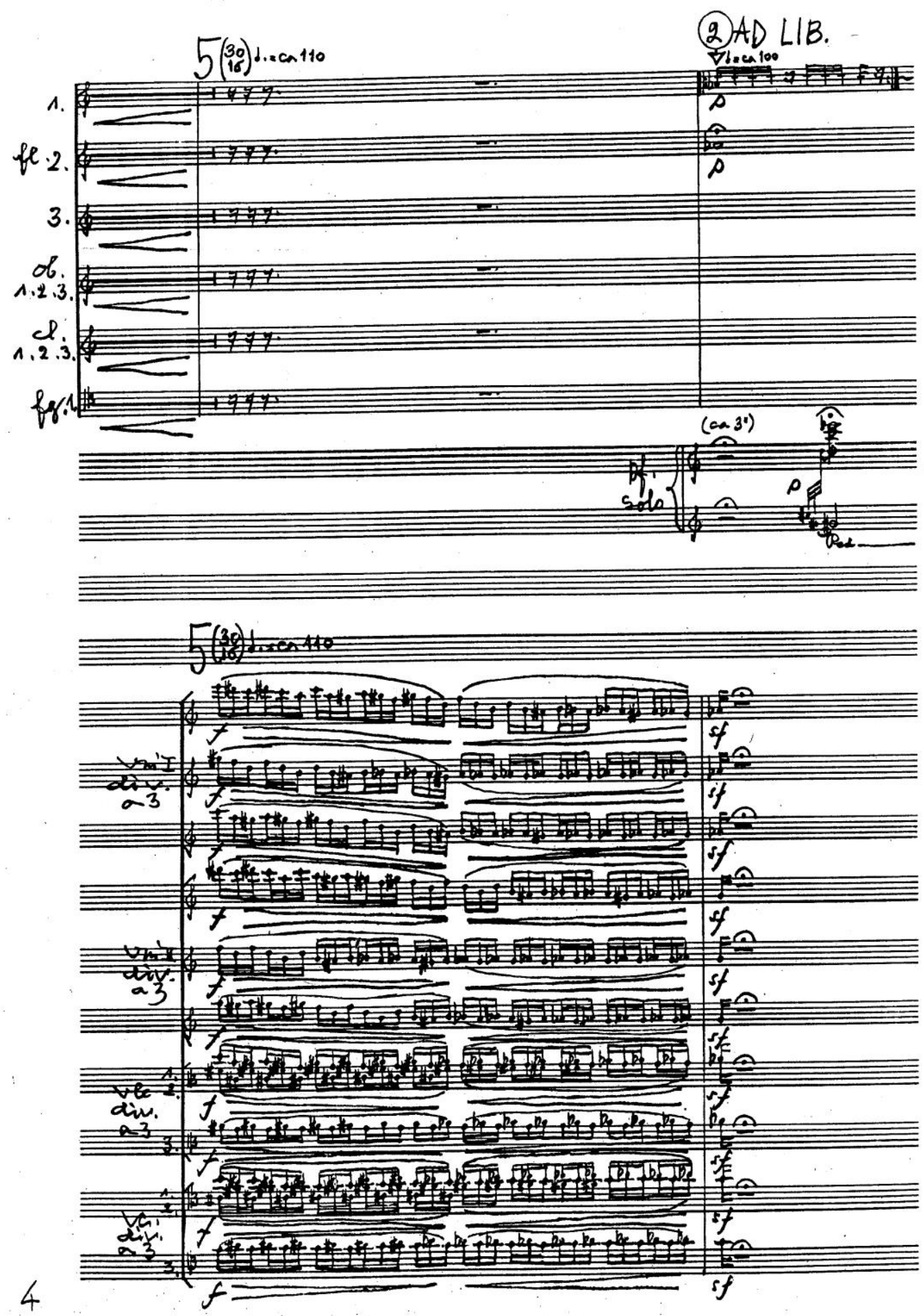

Ryc. 13 
Poszczególne kroki, z których składa się początek Koncertu fortepianowego zestawia poniższa tabela:

Tabela nr 2: Zestawienie kroków fragmentu Koncertu fortepianowego.

\begin{tabular}{|c|c|c|c|c|c|}
\hline Krok & Znak & $\begin{array}{c}\text { Znak } \\
\text { interpretujący } \\
\text { ruch }\end{array}$ & $\begin{array}{c}\text { Polecenie } \\
\text { dla } \\
\text { dyrygenta }\end{array}$ & $\begin{array}{c}\text { Polecenie } \\
\text { dla } \\
\text { orkiestry }\end{array}$ & $\begin{array}{l}\text { Warunek } \\
\text { przejścia }\end{array}$ \\
\hline 1 & & $\|$ & $\begin{array}{l}\text { Wykonać } \\
\text { ruch. }\end{array}$ & $\begin{array}{c}\text { Grać swoją } \\
\text { partię } \\
\text { w ciągłej } \\
\text { repetycji. }\end{array}$ & $\begin{array}{c}\text { Pierwszy } \\
\text { flet, } \\
\text { pierwszy } \\
\text { obój } \\
\text { i klarnety } \\
\text { zagrały swój } \\
\text { fragment } \\
\text { i powtarzają } \\
\text { go. }\end{array}$ \\
\hline 2 & & -1 & $\begin{array}{c}\text { Wskazać } \\
\text { kolejno pięć } \\
\text { wejść - dla } \\
\text { pięciu } \\
\text { muzyków. }\end{array}$ & $\begin{array}{c}\text { Grać swoją } \\
\text { partię } \\
\text { w ciąglej } \\
\text { repetycji. }\end{array}$ & $\begin{array}{l}\text { Pięcioro } \\
\text { muzyków, } \\
\text { którym } \\
\text { dyrygent } \\
\text { wskazał } \\
\text { wejścia } \\
\text { realizuje } \\
\text { swoją partię } \\
\text { w ciągłej } \\
\text { repetycji. }\end{array}$ \\
\hline 3 & $\begin{array}{l}\text { Ozn. } \\
\text { metrum } \\
5 / 4\end{array}$ & 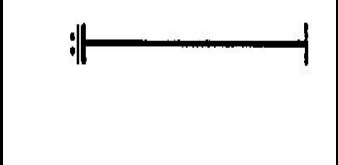 & $\begin{array}{l}\text { Rozpocząć } \\
\text { dyrygowanie } \\
\text { na } 5 .\end{array}$ & $\begin{array}{l}\text { Przerwać } \\
\text { grę. }\end{array}$ & KONIEC \\
\hline
\end{tabular}

Analizując powyższe wyniki autor doszedł do wniosku, że zbiór znaków graficznych, który Witold Lutosławski zastosował w swoich partyturach uznać można za język formalny, za pomocą którego zanotowane zostały komunikaty o różnym stopniu złożoności. Przez język formalny rozumiem za Zygmuntem Saloni twór formalny zbudowany jako dosyć daleki odpowiednik języka naturalnego. U jego podstaw leży przeświadczenie, że język może być poprawnie zdefiniowany jako zbiór symboli służących do budowy komunikatów językowych oraz zbiór realnych i potencjalnych komunikatów (Saloni 1999: 270). 
Znak, z którego dyrygent odczytuje polecenie „wykonaj ruch" przekazuje najmniejszą ilość informacji wśród analizowanych symboli. Dwie sytuacje, które kompozytor może zadysponować używając tego znaku to wykonanie ruchu i brak ruchu, zatem mamy do czynienia z układem zero-jedynkowym. Można ilość informacji zawartą w strzałce porównać do bitu, który określa jeden $\mathrm{z}$ dwóch podstawowych stanów: o lub 1 (Saloni 1999: 77), w opisywanym przypadku: pojedynczy ruch, lub jego brak.

Znaki polecające wykonanie dyrygentowi pojedynczego ruchu, jak i te przekazujące większą ilość informacji, tworzą proste komunikaty, na których odbiorcami są wykonawcy. Te proste komunikaty zapisane są w poszczególnych wierszach tabel.

Wewnętrznie uporządkowane ciągi komunikatów prostych tworzą złożone instrukcje działania. Można te instrukcje nazwać algorytmami, lub programami. Celną definicję podaje Peter Wegner, definiując program jako zestaw (sekwencję) kroków, które należy wykonać w celu rozwiązania problemu i które muszą być możliwe do wykonania czy to przez człowieka, czy komputer (Wegner 2003).

\section{Przejścia między krokami}

Należy wskazać na pewne specyficzne cechy poszczególnych instrukcji prostych, mianowicie na warunek przejścia pomiędzy nimi (ich opisy zawarte są w ostatniej kolumnie tabel). W aleatoryzmie kontrolowanym Witolda Lutosławskiego obserwujemy dwa rodzaje przejść: sekwencyjne i iteracyjne. Sekwencyjne przejście występuje, gdy warunkiem wykonania kolejnego kroku instrukcji jest zrealizowanie całej partii, lub upłynięcie określonego czasu. Taka sytuacja występuje np. we fragmencie Koncertu wiolonczelowego przedstawionego na poniższej rycinie. 

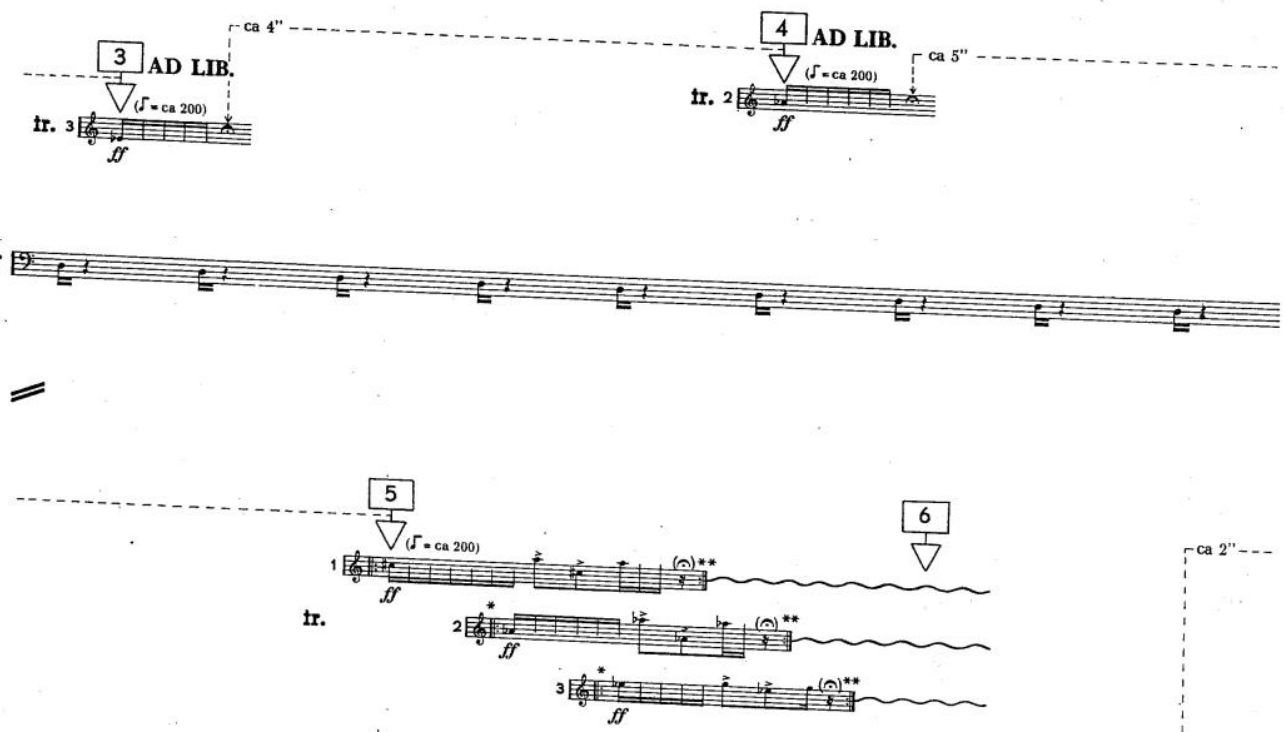

$\underset{\text { solo }}{\text { vc. }}$
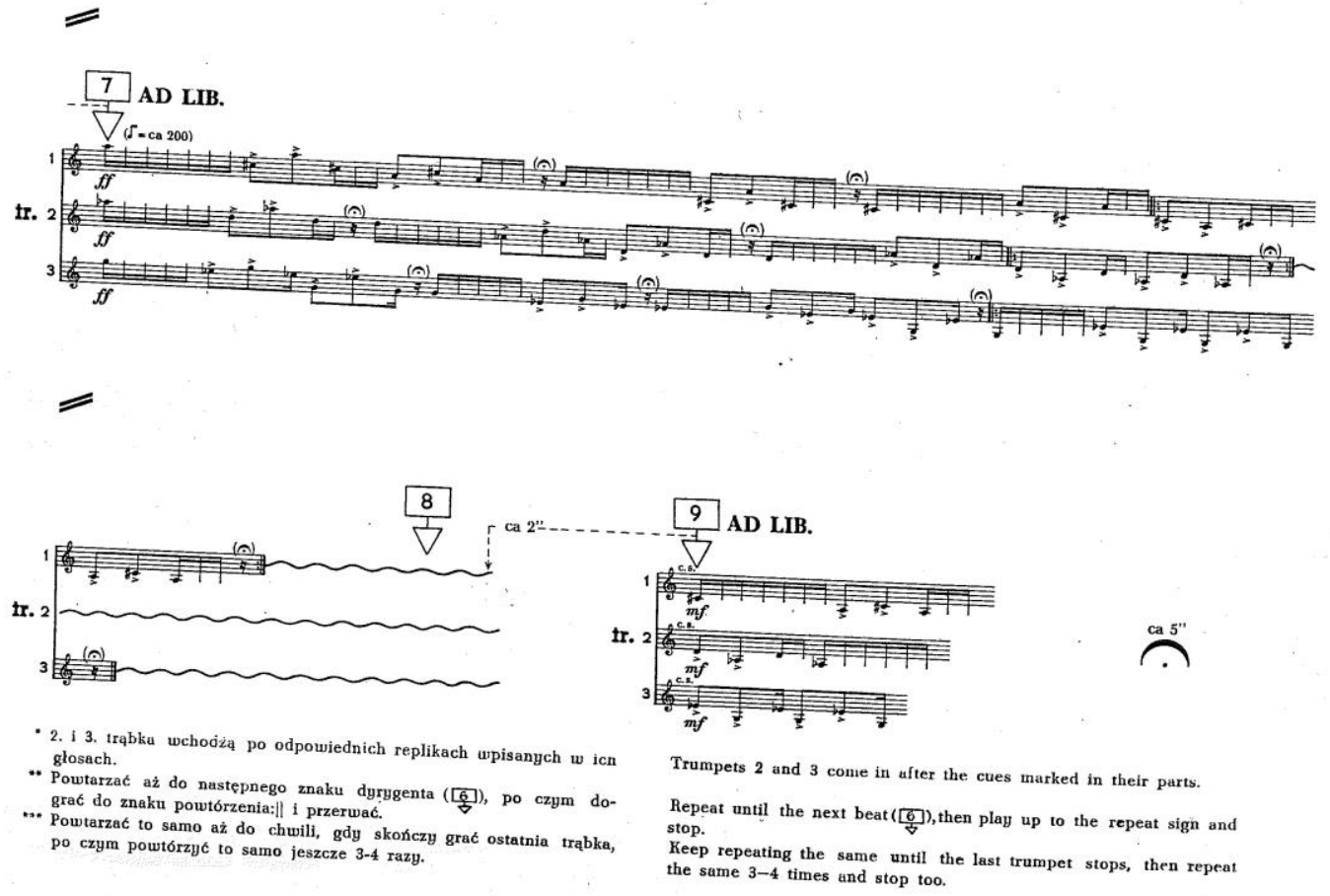

Ryc. 14

Trębacz musi wykonać zapisane sześć nut (strzałka $\mathrm{nr}$ 4, na górze partytury), po czym krok uznaje się za zrealizowany i przechodzi dalej. Konstrukcję tej instrukcji przedstawia poniższa tabela. 
Tabela nr 3: Parametry odcinka 4-5 Koncertu wiolonczelowego.

\begin{tabular}{|c|c|c|c|}
\hline Znak & $\begin{array}{c}\text { Polecenie dla } \\
\text { dyrygenta }\end{array}$ & $\begin{array}{c}\text { Polecenie dla } \\
\text { orkiestry }\end{array}$ & $\begin{array}{c}\text { Warunek } \\
\text { przejścia }\end{array}$ \\
\hline Ty & $\begin{array}{c}\text { Wykonać ruch po } \\
\text { upłynięciu czterech } \\
\text { sekund od } \\
\text { poprzedniego } \\
\text { fragmentu. }\end{array}$ & $\begin{array}{c}\text { Wykonać } \\
\text { zapisane } \\
\text { dźwięki. }\end{array}$ & $\begin{array}{c}\text { Zrealizowanie } \\
\text { partii przez } \\
\text { trębacza } \\
\text { i upłynięcie } \\
\text { kolejnych pięciu } \\
\text { sekund. }\end{array}$ \\
\hline
\end{tabular}

W sekwencyjnym przejściu pomiędzy pojedynczymi instrukcjami decydującym czynnikiem może też być wyłącznie upłynięcie określonego czasu. Taką sytuację można zaobserwować w w tym samym fragmencie partytury, na dole, po ruchu nr 8. Dyrygent musi poczekać 2 sekundy od momentu zamilknięcia trąbek i dopiero wykonać kolejny ruch, oznaczony numerem 9. Tę instrukcję opisuje poniższa tabela.

Tabela 4: Parametry odcinka 8-9 Koncertu wiolonczelowego.

\begin{tabular}{|l|l|c|c|c|}
\hline Znak & $\begin{array}{c}\text { Znak } \\
\text { interpretujący } \\
\text { ruch }\end{array}$ & $\begin{array}{c}\text { Polecenie } \\
\text { dla } \\
\text { dyrygenta }\end{array}$ & $\begin{array}{c}\text { Polecenie } \\
\text { dla } \\
\text { orkiestry }\end{array}$ & $\begin{array}{c}\text { Warunek } \\
\text { przejścia }\end{array}$ \\
\hline Itrmm & $\begin{array}{c}\text { Po ruchu } \\
\text { czekać, aż } \\
\text { trębacze } \\
\text { przestaną grać } \\
\text { i policzyć 2 } \\
\text { sekundy }\end{array}$ & $\begin{array}{c}\text { Po ruchu } \\
\text { dyrygenta } \\
\text { dograć do } \\
\text { znaku } \\
\text { repetycji i } \\
\text { przerwać grę }\end{array}$ & $\begin{array}{c}\text { Upłynięcie 2 } \\
\text { sekund ciszy }\end{array}$ \\
\hline
\end{tabular}

Sekwencyjne przejście pomiędzy instrukcjami jest to proste następstwo kolejnych czynności. Witold Lutosławski zastosował także bardziej wyrafinowane narzędzie - powtarzanie instrukcji w pętli, aż do wystąpienia określonego warunku. Jest to iteracja, czyli powtarzanie czynności (lub linijki kodu) do momentu, wystapienia pewnych warunków, np. wszystkie głosy graja w ciagłej repety cji (Huskey 2003). 
Przykładem takiego iteracyjnego przejścia jest przeanalizowany już fragment początku Koncertu fortepianowego. Autor przytacza go jeszcze raz, by wskazać na iteracyjny sposób przechodzenia pomiędzy krokami.

Na rycinie nr 15 można zaobserwować sytuację, podczas realizacji której dyrygent będzie czekal, aż oznaczony fragment będzie nieustannie powtarzany (w pętli), dopiero wtedy wykona pięć ruchów. Ten moment zaobserwować można na poniższej rycinie.

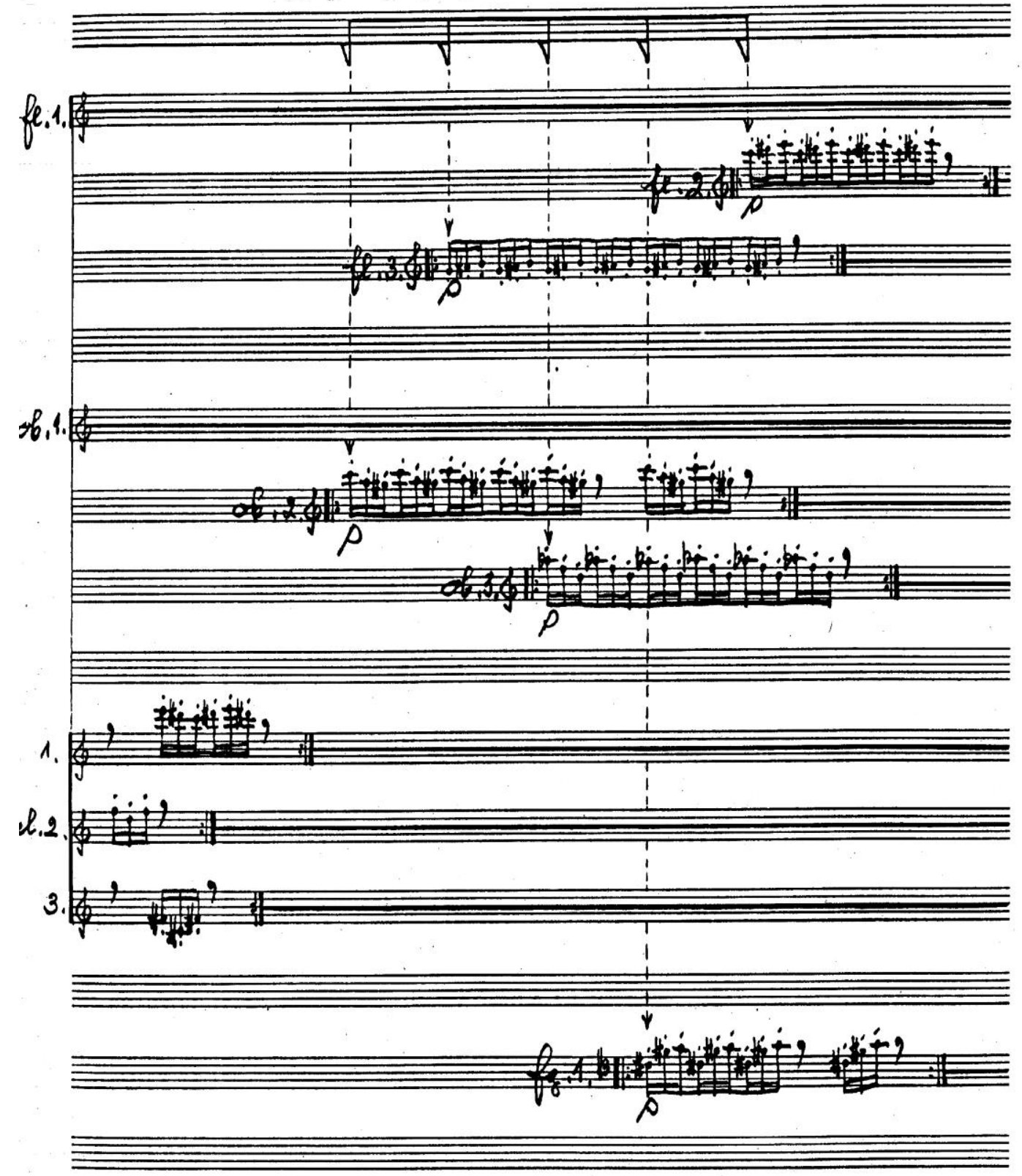

Ryc. 15 
Tabela opisująca ten krok przedstawiona jest poniżej.

Tabela nr 5: Analiza znaków.

\begin{tabular}{|c|c|c|c|c|}
\hline Znak & $\begin{array}{c}\text { Znak } \\
\text { interpretujący } \\
\text { ruch }\end{array}$ & $\begin{array}{c}\text { Polecenie } \\
\text { dla } \\
\text { dyrygenta }\end{array}$ & $\begin{array}{l}\text { Polecenie } \\
\text { dla } \\
\text { orkiestry }\end{array}$ & $\begin{array}{l}\text { Warunek } \\
\text { przejścia }\end{array}$ \\
\hline \begin{tabular}{l|l|l|l}
1 & 1 & 1 & 1 \\
\end{tabular} & $: \Vdash$ & $\begin{array}{c}\text { Czekać, aż } \\
\text { wskazane } \\
\text { partie będą } \\
\text { grane w } \\
\text { ciąglej } \\
\text { repetycji. }\end{array}$ & $\begin{array}{c}\text { Realizować } \\
\text { swoje partie } \\
\text { w } \\
\text { nieustannej } \\
\text { repetycji. } \\
\text { Flet } 2,3 \text {, obój } \\
2,3 \text {, fagot } 1 \text { - } \\
\text { czekać na } \\
\text { pięć ruchów } \\
\text { dyrygenta. }\end{array}$ & $\begin{array}{c}\text { Spełnienie } \\
\text { warunku } \\
\text { realizacji } \\
\text { partii w } \\
\text { ciągłej } \\
\text { repetycji. }\end{array}$ \\
\hline
\end{tabular}

\section{Wnioski}

Na podstawie powyższych rozważań można stwierdzić, że partytura Witolda Lutosławskiego jest szczególnym rodzajem zapisu muzycznego. Nie próbuje oddać za pomocą nut brzmienia utworu, które dopiero doświadczony w sztuce odczytywania notacji muzyk odtworzy najpierw w wyobraźni, a później na estradzie, lecz jest instrukcją postępowania dla wykonawców. Kompozytor zastosował element przypadkowości, ale zakomponował jego użycie bardzo ściśle, jedynie w zakresie, w którym przypadkowość dopuszcza. Wykonawcy, pomimo pozornej wolności zawartej w zapisie (brak ścisłego rygoru rytmicznego, brak wymogu wertykalnej jednoczesności różnych partii) nie są w stanie wyjść poza koncepcję kompozytora podczas realizacji tego zapisu. Dzięki tej specjalnej metodzie notacji muzyki Witold Lutosławski zagwarantował sobie miejsce w centrum sytuacji estetycznej. Zapis, którego punktem wyjścia jest wskazanie dyrygentowi momentów wykonania ruchów, gwarantuje nadrzędność elementu kontroli w stosunku do aleatoryczności, przypadkowości, gwarantuje kompozytorowi kontrolę nad brzmieniem dzieła. 


\section{Bibliografia}

Gwizdalanka, D., Meyer. K. 2004. Lutostawski. Droga do mistrzostwa, Kraków: PWM.

Huskey, H. D., 2003. Iteration. w: A. Ralston, E. D. Reilly, D. Hemmendinger (Ed.) Encyclopedia of Computer Science 4th Edition Chichester: John Willey and Sons Ltd.

Lutosławski, W. 1967. O roli elementu przypadku $w$ technice komponowania. $w$ : Res facta $\mathrm{nr} 1$

Lutosławski, W. 1971. Koncert wiolonczelowy, partytura Kraków: PWM.

Lutosławski, W. 1991. Łańcuch I partytura Kraków: PWM.

Lutosławski, W. 1991. Koncert fortepianowy partytura, Kraków: PWM.

Pociej, B. 1976. Lutostawski a wartość muzyki, Kraków: PWM.

Saloni, Z. 1999. Komunikat. w: K. Polański (red.) Encyklopedia językoznawstwa ogólnego Wrocław: Zakład Narodowy im. Ossolińskich, s. 307.

Saloni, Z. 1999. Język formalny. w: K. Polański (red.) Encyklopedia językoznawstwa ogólnego Wrocław: Zakład Narodowy im. Ossolińskich, s. 270.

Saloni, Z. 1999. Bit. w: K. Polański (red.) Encyklopedia językoznawstwa ogólnego Wrocław: Zakład Narodowy im. Ossolińskich, s. 77.

Wegner, P. 2003. Program. w: A. Ralston, E. D. Reilly, D. Hemmendinger (Ed.) Encyclopedia of Computer Science 4th Edition Chichester: John Willey and Sons Ltd. 